\title{
Dressing percentage and carcass characteristics of Bunaji bulls fattened on varying inclusion levels of groundnut haulms and maize offal \\ ${ }^{1}$ Goska, D. Y., ${ }^{2}$ Kibon, A., ${ }^{1}$ Madziga, I. I., ${ }^{3}$ Alawa, C. B. I., ${ }^{1}$ Lamidi, O. S., ${ }^{1}$ Voh, A. A., ${ }^{1}$ Iyeghe -Erakpotobor, G. T. and ${ }^{4}$ Yakubu, B. and ${ }^{5}$ Dauda, J. \\ ${ }^{1}$ National Animal Production Research Institute, Ahmadu Bello University, Shika-Zaria, Nigeria. \\ ${ }^{2}$ Department of Animal Science, Federal University Dutse, Nigeria \\ ${ }^{3}$ Department of Animal Health and Production, Faculty of Veterinary Medicine, University of Abuja, Nigeria. \\ ${ }^{4}$ Department Animal Science

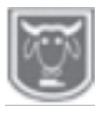 \\ Abstract \\ Modibbo Adama University of Technology, Yola, Nigeria. \\ ${ }^{5}$ Department Animal Science, Ahmadu Bello University Zaria Nigeria \\ *Corresponding author: goskady@gmail.com
}

Animal carcasses vary in composition through genetic, age and sex of animal, nutritional and environmental effects. Twenty Bunaji bulls with average live weights of $196 \pm 0.5 \mathrm{~kg}$ and aged between $2^{1}{ }_{2}$ and 3 years were used for the trial. The bulls were divided to four groups of five animals balanced by weight with an animal as a replicate in a completely randomized design and were allocated to four dietary treatments consisting of 80:20, 60:40, 40:60 and 20:80\% groundnut haulms: maize offal. Feed intake, live and carcass weights and weight of carcass components and offal were used to assess the carcass characteristics. Feed intake and final weight differed $(P<0.05)$ significantly with the bulls on 40: 60 and 20: 80\% groundnut haulms: maize offal inclusion levels having higher values of 7.49 and $7.57 \mathrm{~kg} / \mathrm{d}$ and 276.60 and $279.60 \mathrm{~kg}$ against 6.93 and $7.16 \mathrm{~kg} / \mathrm{d}$ and 242.40 and $252.60 \mathrm{~kg} / \mathrm{d}$ for those on $80: 20$ and 60: 40\% inclusion levels, respectively. Similarly, feed conversion ratio was significantly $(P<0.05)$ higher for the bulls on 40: 60 and 20:80\% inclusion levels than those on 80: 20 and 60: 40\% inclusion levels. The carcass components used were: empty carcass (kg), dressing percentage, weight of dissectible beef $(\mathrm{kg})$, beef yield \% of carcass weight, internal offal (liver, spleen, heart, kidney, empty stomach and intestine) and external offal (head, tail, legs and hide). Result also showed that there was significant $(P<0.05)$ difference in all the carcass components, dressing percentage and weight of legs spleen, kidney and empty intestines between the treatments. However, no differences were observed for the weights of liver, heart, empty stomach, head and hide. It is concluded that higher proportion of maize offal in the diet influence most carcass components.

Keywords: Dressing percentage, Carcass characteristics, Bunaji bulls, groundnut haulms and maize offal.

\section{Introduction}

The Bunaji (White Fulani) breed of cattle is one of the breeds mostly fattened by smallholder fatteners in Nigeria. Others are Rahaji, and Bokoloji or Sokoto Gudali (Adamu and Alawa, 2005; Alawa et al., 2007). Reports on institutional fattening trials in the country Olayiwola et al., 1981; Ikhatua and Olayiwole, 1982) showed appreciable increase of $25-40 \%$ in the liveweight of the indigenous breeds of cattle fattened in feedlots. However, cattle fattening using the conventional feed ingredients like maize grain, silage, groundnut cake and cotton seed cake has been very difficult to adopt by the smallholder farmers due to the high cost of such ingredients. The major constraint in ruminants' production in the country and indeed most sub-Sahara African countries 
among others is inadequate nutrition owing to the seasonality of qualitative and quantitative herbage leading to reduced animal performance through body weight and condition loss as well as reduced carcass composition is common especially during the dry season (Lamond, 1970; Deaville et al., 1994) The constraint of poor nutrition in beef production could be minimized by finishing animals in feedlot using diets based on crop residues and agro-processing by-products. Using crop residues in animal feed can be interesting when it results in low cost for the process, provided it maintains the animal production index and satisfactory animal performance (Roth et al., 2009). Groundnut haulms along with cowpea, soybean threshing and cereals bran are major crop residues and agro-processing by-products used for animal fattening in the West African Sahel and other tropical countries (Ayantunde et al., 2007; An, 1998; Lamidi et al., 2008). Groundnut tops (haulms) after pod harvesting provides important feed resources for livestock production and is extensively fed to ruminants especially in the dry season $(\mathrm{Njie}$ and Reed, 1995; Olorunju et al., 1996). An estimated 1.3 million tonnes of groundnut haulms are reported to be produced annually in the seven major groundnut producing states of Sokoto, Kano, Bauchi, Kaduna, Benue, Borno and Adamawa ((Alhassan,1985). Tarawali and Quee (2014) also reported groundnut haulms yield per hectare to be around 1,650 to $1808 \mathrm{~kg}$ depending on varieties and ecological zone of production. Groundnut haulms is of high nutritive value (Ayoade $e t$ al., 1983; Ikhatua and Adu, 1984) and have been used intensively to supplement poor quality cereal Stover during the long (5-7 months) dry season in the Northern Guinea Savanna zone of Nigeria (Lamidi et al., 2006). Maize offal is a by-product obtained from maize grain processing. It is a mixture of bran, middling, and some cobs. Maize offal is commonly used as feed for livestock in northern Nigeria where maize is largely produced. Maize offal is moderate in $\mathrm{CP}$ $(10.82 \%)$ and is high in energy $\left(3,432 \mathrm{Kcal}^{-}\right.$ ${ }^{1}$ Metabolizable energy) and it is reported to contain $91.80 \%$ dry matter, $12.70 \%$ crude protein, $8.90 \%$ ether extract, $12.80 \%$ crude fibre, $6.50 \%$ Ash, $50.80 \%$ nitrogen free extract, $43.00 \%$ acid detergent fibre, and $4.25 \mathrm{kcal} / \mathrm{g} \mathrm{GE}$ (Olorunnisomo et al., 2006). Animal carcasses vary in composition through genetic, age and sex of animal, nutritional and environmental effects. Although heredity dictates the maximum amount of growth and development that is possible, nutrition along with other environmental factors governs the actual rate of growth and extent to which development is attained (Irshad et al., 2012). Dressing percentage and other carcass characteristics gives the farmer valuable idea with which to estimate expected returns.

The study aimed at evaluating the effect of varying the proportion of groundnut haulms and maize offal as protein and energy supplements respectively on carcass characteristics of bulls to maximize the use of these feed ingredients to increase beef production and reduce animal protein deficiency in the diet of the resource poor.

\section{Materials and methods \\ Location of the study}

The study took place at the meat laboratory of The National Animal Production Research Institute (NAPRI) Ahmadu Bello University, Shika Zaria Nigeria. Shika is located within the Northern Guinea Savanna ecological zone of the country between latitude of 11 and $12^{\circ} \mathrm{N}$ and between longitudes 7 and $33^{\circ} \mathrm{E}$ at an altitude of $640 \mathrm{~m}$ above sea level. The zone has one wet season that starts from May/ June and 


\section{Goska, Kibon, Madziga, Alawa, Lamidi, Voh, Iyeghe -Erakpotobor, Yakubu and Dauda}

ends in October. Mean annual rainfall is about $1041 \mathrm{~mm}$; maximum temperature varies between $27^{\circ} \mathrm{C}$ and $35^{\circ} \mathrm{C}$ depending on the season while relative humidity is about $72 \%$.

\section{Animals and design of experiment}

Twenty Bunaji bulls with average live weights of $196 \pm 0.5 \mathrm{~kg}$ were used for the trial. The bulls were divided into four groups of five animals balanced by weight with an animal as a replicate in a completely randomized design and were allocated to four dietary treatments. The bulls were dewormed with Albendazole 2500mg ( E a g le Chemical Co. L t d chungchongnamdo, Korea) and dipped in acaricides Amitix (Amitraz 12.5\% by Alfasan) to control endo- and ectoparasites a week to commencement of the trial. The bulls were individually penned and fed. The bulls were fed $1 \mathrm{~kg} /$ head/day of supplement ration and ad libitum Signal grass hay for 14 days to adjust the bulls to the various diets. After the adjustment period, supplements were offered at $2 \%$ of the animal's body weight, while Brachiaria hay was offered as a basal diet. These were weighed before feeding. Half of the days' concentrate was offered in the morning (between 8 and 9 am) and the remaining half was offered in the afternoon (between 4 and $5 \mathrm{pm}$ ). Water and mineral salt block were offered ad-libitum. Feed remnants were weighed the following day in the morning before the day's feed was offered. The animals were weighed weekly and their feed offer adjusted accordingly. The study lasted 90 days and took place between May and August.

\section{Carcass evaluation}

Two bulls from each treatment were slaughtered to determine carcass composition. The bulls were slaughtered after 24 hours of feed and water withdrawal to shrunk body weight. After slaughter, the external offal (head, limb, tail and hide) were removed and weighed separately. After evisceration the internal offal (liver, spleen, kidney, heart and lungs) were removed and weighed individually. Empty carcass weight was obtained by weighing the carcass after the removal of thoracic and abdominal viscera. Dressing percentage was obtained by dividing empty carcass weight by fasted body weight expressed in percentage. The GIT was weighed with the contents and re -weighed after washing. Total lean meat (Boneless) was separated and weighed. The bones were also weighed.

\section{Statistical analysis}

To determine the response of the animals to treatments, all data collected were subjected to Analysis of Variance using the General Linear Model Procedure (GLM) of SAS (2002). Significant levels of difference among treatment means was separated by Duncan Multiple Range Test (Duncan, $1955)$ at 5 and $1 \%$ level of significance. The model used for the analysis was $\mathrm{Y}_{\mathrm{ij}}=$ $\mu+\mathrm{T}_{\mathrm{i}}+\mathrm{eij}$

Where $\mu=$ Overall means

$\mathrm{T}_{\mathrm{i}}=$ effect of $\mathrm{i}^{\text {th }}$ treatment $(\mathrm{i}=1,2,3,4)$

eij= random error (The random effect assumed to be normally distributed with mean zero and equal variance ${ }^{2}$ i.e $\Sigma \sim \mathrm{N}(0$, ${ }_{1}^{2}$ )

\section{Results and discussion}

The crude protein (CP) content of signal grass hay used for this study was low, typical of tropical forage grasses that are reported to be of low CP at advance stage of growth (Minson, 1971). Signal grass is a tropical forage grass reported to contain 3.2 to $17.5 \% \mathrm{CP}$ depending on soil fertility, management and stage of growth (Loch, 1977). The CP value of signal grass (which was harvested after seeding) agrees with the report by Sampaio et al. (2010) (4.86\%) and was below the $7-8 \%$ required for maintenance of body weight and critical for 
microbial growth and roughage intake (Warly et al., 1992; Fall, 1990; Abdulrazak et al., 2005) and therefore can be regarded as a low quality feed (Leng, 1990). Therefore it was necessary to supplement the bulls with protein sources. The crude fibre content of signal grass was within the range reported by Loch (1977) and within the minimum level $(17 \%)$ required by beef cattle (NRC, 2000). The CP content of GH was within the range reported by Abubakar et al. (2010); Addass et al. (2011) and Jadalla et al. (2012) but was higher than the value (11.22) reported by Lakpini and Adu (1987). However, the value reported in this work was lower than reported by IyegheErakpotobor et al. (2006). This might be due to differences in stage of growth at harvest and preservation method. The $\mathrm{CP}$ content of $\mathrm{GH}$ fed with $\mathrm{MO}$ met the requirement of the bulls, hence the reasonable weight gain obtained. The digestible $\mathrm{CP}$ value of $\mathrm{GH}$ is reported to be superior to non-leguminous hays and is comparable to that of leguminous cowpea. Groundnut haulms can be safely fed along with wheat bran to meet the entire nutritional requirement of lactating cow producing 5 liters of milk per day (Ranjhan, 1993). The CP content of maize offal $(12.65 \%)$ was in agreement with the report by Vantsawa et al. (2007). This contributed significantly to the $\mathrm{CP}$ supplied from the concentrate mixtures. The significant differences observed in final weight, weight gain, average daily gain and feed conversion (Table 2) between treatments might have resulted to the variation in the dressing percentage and the weight of most carcass components(dissectible beef, beef yield as percentage of carcass weight and meat : bone ratio) with increasing level of maize offal inclusion. This agrees with the report by Rotta et al. (2009) that the feeding system and the diet can influence cattle carcass and meat characteristics. It has also been demonstrated that carcass traits including dressing percentage are influenced by several factors such as plane of nutrition, sex and age of the animal (Devendra and Burns, 1983).

Table 1: Ingredients and chemical composition of the concentrates with inclusion levels of groundnut haulms and maize offal (\%)

\begin{tabular}{|c|c|c|c|c|}
\hline \multicolumn{5}{|c|}{ Inclusion levels of GH and MO (\%) } \\
\hline \multirow{3}{*}{ Nutrients } & $\mathrm{T}_{1}$ & $\mathrm{~T}_{2}$ & $\mathrm{~T}_{3}$ & $\mathrm{~T}_{4}$ \\
\hline & GH: MO & GH: MO & GH: MO & GH: MO \\
\hline & 80: MO & 60: 40 & 40: 60 & 20: 80 \\
\hline Groundnut haulms & 80.00 & 60.00 & 40.00 & 20.00 \\
\hline Maize offal & 19.06 & 38.91 & 58.80 & 78.70 \\
\hline Urea & 0.94 & 1.09 & 1.20 & 1.30 \\
\hline Total & 100.00 & 100.00 & 100.00 & 100.00 \\
\hline \multicolumn{5}{|l|}{ Chemical composition } \\
\hline Dry matter & 95.71 & 95.20 & 94.46 & 94.29 \\
\hline Crude protein & 16.38 & 16.41 & 16.43 & 16.25 \\
\hline Crude fibre & 24.94 & 21.17 & 17.01 & 13.53 \\
\hline Ether extract & 8.17 & 10.71 & 11.15 & 12.15 \\
\hline Organic matter & 88.16 & 94.78 & 94.99 & 95.81 \\
\hline Neutral detergent fibre & 40.04 & 36.46 & 31.08 & 32.21 \\
\hline Acid detergent fibre & 30.30 & 22.21 & 19.75 & 15.91 \\
\hline Ash & 11.84 & 5.22 & 5.01 & 4.19 \\
\hline $\mathrm{ME}(\mathrm{MJ} / \mathrm{Kg} \mathrm{DM})$ & 10.98 & 10.89 & 11.04 & 11.16 \\
\hline
\end{tabular}


Goska, Kibon, Madziga, Alawa, Lamidi, Voh, Iyeghe -Erakpotobor, Yakubu and Dauda

Table 2: Performance characteristics of bunaji bulls fed varying inclusion levels of groundnut haulms and maize offal (\%)

\begin{tabular}{|c|c|c|c|c|c|}
\hline \multirow{4}{*}{ Parameters } & \multicolumn{3}{|c|}{ Inclusion levels of $\mathrm{GH}$ and $\mathrm{MO}(\%)$} & \multirow[b]{2}{*}{$\mathrm{T}_{4}$} & \multirow{4}{*}{ SEM } \\
\hline & $\mathrm{T}_{1}$ & $\mathrm{~T}_{2}$ & $\mathrm{~T}_{3}$ & & \\
\hline & GH: MO & GH: MO & GH: MO & GH: MO & \\
\hline & 80: 20 & 60: 40 & 40: 60 & 20: 80 & \\
\hline Dry matter intake (kg) & $6.93^{c}$ & $7.16^{\mathrm{b}}$ & $7.49^{\mathrm{a}}$ & $7.57^{\mathrm{a}}$ & $0.02^{*}$ \\
\hline Initial weight & 197.00 & 196.80 & 197.20 & 196.80 & $3.61 \mathrm{~ns}$ \\
\hline Final weight & $242.40^{\mathrm{c}}$ & $252.60^{\mathrm{b}}$ & $276.60^{\mathrm{a}}$ & $279.60^{\mathrm{a}}$ & $4.26^{*}$ \\
\hline Weight change & $45.40^{\mathrm{c}}$ & $55.80^{\mathrm{b}}$ & $79.40^{\mathrm{a}}$ & $82.80^{\mathrm{a}}$ & $2.72^{* *}$ \\
\hline Average daily gain & $0.50^{\mathrm{d}}$ & $0.62^{\mathrm{c}}$ & $0.88^{\mathrm{b}}$ & $0.92^{\mathrm{a}}$ & $0.03^{* *}$ \\
\hline Feed conversion ratio & $13.86^{\mathrm{b}}$ & $16.16^{\mathrm{b}}$ & $8.60^{\mathrm{a}}$ & $8.31^{\mathrm{a}}$ & $1.47^{*}$ \\
\hline
\end{tabular}

Table 3: Dressing percent, weight of hot carcass and edible offal of bunaji bulls fattened on diets containing groundnut haulms and maize offal

\begin{tabular}{|c|c|c|c|c|c|}
\hline \multirow{4}{*}{ Parameters } & \multicolumn{4}{|c|}{ Inclusion levels of $\mathrm{GH}$ and $M O(\%)$} & \multirow[b]{4}{*}{ SEM } \\
\hline & $\mathrm{T}_{1}$ & $\mathrm{~T}_{2}$ & $\mathrm{~T}_{3}$ & $\mathrm{~T}_{4}$ & \\
\hline & GH:MO & $\mathrm{GH}: \mathrm{MO}$ & $\mathrm{GH}: \mathrm{MO}$ & GH:MO & \\
\hline & $80: 20$ & $60: 40$ & $40: 60$ & $20: 80$ & \\
\hline Live weight (Kg) & 249.50 & 250.00 & 263.50 & 265.50 & $18.46^{\mathrm{ns}}$ \\
\hline Empty carcass weight $(\mathrm{Kg})$ & $135.50^{\mathrm{ab}}$ & $133.00^{\mathrm{b}}$ & $155.50^{\mathrm{a}}$ & $150.00^{\mathrm{ab}}$ & $11.18^{*}$ \\
\hline Dressing percent & $54.27^{\mathrm{c}}$ & $53.19^{c}$ & $58.91^{\mathrm{a}}$ & $56.43^{\mathrm{b}}$ & $0.86^{*}$ \\
\hline Weight of dissectible beef $(\mathrm{Kg})$ & $74.50^{\mathrm{b}}$ & $70.50^{\mathrm{b}}$ & $89.75^{\mathrm{a}}$ & $80.50^{\mathrm{ab}}$ & $7.46^{*}$ \\
\hline $\begin{array}{l}\text { Beef yield ( } \% \text { of carcass } \\
\text { weight) }\end{array}$ & $54.89^{\mathrm{ab}}$ & $52.45^{\mathrm{b}}$ & $57.66^{\mathrm{a}}$ & $53.83^{\mathrm{b}}$ & $1.88^{*}$ \\
\hline Bone yield $(\mathrm{Kg})$ & $11.85^{\mathrm{ab}}$ & $11.25^{\mathrm{b}}$ & $12.50^{\mathrm{a}}$ & $13.00^{\mathrm{a}}$ & $0.64^{*}$ \\
\hline Meat :bone ratio & $6.25^{\mathrm{ab}}$ & $6.20^{\mathrm{b}}$ & $7.22^{\mathrm{a}}$ & $6.22^{\mathrm{ab}}$ & $0.50^{*}$ \\
\hline Legs $(\mathrm{Kg})$ & $6.25^{\mathrm{b}}$ & $6.25^{\mathrm{b}}$ & $6.6^{\mathrm{ab}}$ & $6.77^{\mathrm{a}}$ & $0.25^{*}$ \\
\hline Hide $(\mathrm{Kg})$ & 17.50 & 16.00 & 18.75 & 19.00 & $2.11^{\mathrm{ns}}$ \\
\hline Head (Kg) & 17.75 & 16.50 & 16.65 & 17.50 & $1.02^{\mathrm{ns}}$ \\
\hline Liver $(\mathrm{Kg})$ & 3.50 & 4.20 & 4.00 & 3.67 & $0.45^{\mathrm{ns}}$ \\
\hline Spleen (Kg) & $0.65^{\mathrm{b}}$ & $0.60^{\mathrm{b}}$ & $0.62^{\mathrm{b}}$ & $1.05^{\mathrm{a}}$ & $0.04^{*}$ \\
\hline Heart $(\mathrm{Kg})$ & 0.85 & 0.77 & 0.80 & 0.90 & $0.08^{\mathrm{ns}}$ \\
\hline Kidney (Kg) & $0.52^{b}$ & $0.62^{\mathrm{ab}}$ & $0.45^{\mathrm{b}}$ & $0.70^{\mathrm{a}}$ & $0.05^{*}$ \\
\hline Empty stomach $(\mathrm{Kg})$ & 8.70 & 8.45 & 7.25 & 7.55 & $0.74^{\mathrm{ns}}$ \\
\hline Empty intestine $(\mathrm{Kg})$ & $5.65^{\mathrm{ab}}$ & $6.49^{\mathrm{a}}$ & $5.75^{\mathrm{ab}}$ & $5.35^{\mathrm{b}}$ & $0.44^{*}$ \\
\hline
\end{tabular}

abc Means with different superscripts along the row differ significantly $(\mathrm{P}<0.05)$,

$\mathrm{ns}=$ not significant, $*=\mathrm{P}<0.05, \mathrm{SEM}=\mathrm{s}$ tandard error of means, $\mathrm{GH}=$ Groundnut haulms,

$\mathrm{MO}=$ Maize offal

The weight of empty carcass of the bulls ranged between 133.50 and $155.50 \mathrm{~kg}$. There were similarity $(\mathrm{P}>0.05)$ in empty carcass weight between the bulls fed diets with 80: 20, 60: 40 and 20: 80\%GH; MO inclusion levels. Bulls fed on 40: $60 \% \mathrm{GH}$ : MO inclusion level had significantly
$(\mathrm{P}<0.05)$ higher empty carcass weight than those fed 60: 40\%GH: MO inclusion level. Dressing percentage of the bulls in this study which ranged from 53.19 to58.91\% was higher than the report of Olayiwole et al. (1975) and Lamidi et al. (2007) for Bunaji bulls. However, it was lower than 
Dressing percentage and carcass characteristics of Bunaji bulls fattened on varying inclusion levels of groundnut haulms and maize offal

$64.43-66.26,69.4$ and $69.54 \%$ reported by Lamidi (2005); Buvanendran et al. (1981) and Madziga et al. (2016) for Bunaji breed. The report in this study did not agree with the report by Micheal et al. (2002) that there was no difference in dressing percentage in Zebu oxen fed teff straw and supplemented with different levels of wheat bran. Differences in dressing percentage of the bulls in the present study agrees with the report by Feyera and Animut (2011) for Horro sheep supplemented with wheat bran, Acacia albida leaf meal and their mixture and the report by Jabbar and Anjum (2008) for Lohi lambs fattened on different forage to concentrate ratio.

Weight of non-carcass components except legs, spleen and empty intestines were not affected by treatment in agreement with the report by Amani et al. (2009) who showed that nutritional treatment imposed no effect on non-carcass components of Sudan desert lambs.

\section{Conclusion}

From the finding of this study, increasing the proportion of maize offal in a groundnut haulm: maize offal concentrate supplement to an optimum level of $40: 60 \%$ for cattle fattening gave higher carcass dressing percentage, dissectible beef and meat: bone ratio. It was concluded that farmers should feed more of readily fermented energy source to less legume hay as supplements to beef cattle for better return in terms of carcass yield.

\section{Acknowledgement}

The authors are grateful to the Executive Director, National Animal Production Research Institute, Ahmadu Bello University, Zaria for permission to carry out the study and to publish the work. Special thanks to the entire staff of Beef Research Programme for their support and the Central Laboratory unit of National Animal Production Research Institute for laboratory analysis.

\section{References}

Abdulrazak, S. A., Njuguna, E. G. and Karau, P. K. 2005. The effect of Supplementing Rhodes grass (Chloris gayana) hay with Acacia tortilis leave and Pods mixture on intake, digestibility and growth performance of goats. Livestock Research for Rural Development 17:12.

Abubakar, M., Adegbola, T.A. and Abubakar, M.M. 2005. Effect of varying levels of groundnut haulms and cowpea shell on the performance of weaner Red Sokoto goats. Nigerian Journal of Animal Production, 32 (2):274-279.

Abubakar, A., Adegbola, T. A., Abubakar, M. M. Shehu, Y. Ngele, M. B. and Kalla, D. J. U. 2010. Nutritional evaluation of different sources of nitrogen on digestable nutrient intake, nitrogen balance and production of rumen metabolites in growing Yankasa sheep. Emirate Journal of Food and Agriculture 22 ( 4 ) : 298 - 3007 . http://ffa.uaeu.ac.ae/ejfa.shtml.

Adamu, A. M. and Alawa, C. B. I. 2005. Animal nutrition and Cattle Production in Nigeria. Invited Paper presented at the National Workshop on Improving Productivity in Cattle farming in Nigeria. Organized by the National Productivity Centre, Abuja and held at Women Multi-purpose Centre Kaduna. $21^{\text {st }}-22^{\text {nd }}$ September, 2005.

Addass, P. A., Nyako, H. D., Agga, D. P. Mohammed, I. D. Midau, A. J. Fintan, S. and Ja'afar-Furo, M. R. 
Goska, Kibon, Madziga, Alawa, Lamidi, Voh, Iyeghe -Erakpotobor, Yakubu and Dauda

2011. Nutrients evaluation of some common feed resources for cost effective feeding of ruminants in Mubi, Nigeria. Agriculture and Biology Journal of North America 2 ( 1 ) : $15-18$ from http://www.Scihub.org/ABJNA.

Alawa, C. B. I., Aliyu, B. S., Okaiyeto, P. O., Lamidi, O. S. and Adamu, A. M. 2007. A survey of smallholder cattle fattening operations in Kano, Katsina and Jigawa States of Nigerian. Journal of Animal Production Research (2007) 20(1\&2): 53- 63

Amani, A. B. and Salih A. B. 2009. The effect of substitution of groundnut cake by water Melon seed cake( Citrullus Lanatus) in ration for Lamb fattening in Sudan Research Journal of Agriculture and Biological Science, 5(6):11301142, 2009.

Alhassan, W. S. 1985. The potential of agro-industrial by-products and crop residues for sheep and goat production in Nigeria. Proceedings of National Conference on Small Ruminant Production Zaria October 6-10

An, B. X. 1998. Ensiled and dried peanut haulm as replacement of concentrate for Cross bred heifers fed poor quality forages. Livestock Research for Rural Development, Volume10,Number2(

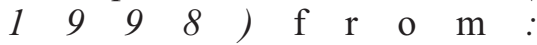
http://ftp.sunet.se/wmirror/www.ci pav.org.co/Irrd/Irrd10/2/an.htm

Ayantunde, A. A., Delfosse, P., Fernandez-Rivera, S., Gerard, B, D a n - G o m m a , 2007 . Supplementation with groundnut haulms for sheep fattening in the We s t A frican S a h 1
(Abstract)Tropical Animal Health and Production, Volume 39,Number 3, April 2007,pp 207$216(10)$ http://www. Ingentaconnect.com/ content/ kiu/trop/2007/00000039/000000 03/00009009

Ayoade, J. A., Makhambera, P. E. and Bodzalenki， M. Z. 1983 . Evaluation of crop residue as feed for goats. Part 1. Voluntary intake, digestibility and nitrogen utilization of bean and groundnut haulms. Herbage Abstracts 56:305.

Buvanendran, V., Ikhatua, U. J., Abubakar, B. and Olayiwole. M. B. 1983. Carcass Characteristics of indigenous breeds of cattle in Nigeria. Journal of Agricultural Science, Cambridge 100:407-411

Deaville, E. A., Angela, R. M and Givens, D. I. 1994. The nutritive value and Chemical composition of energyrich by-products for ruminants. Animal Feed Science Technology 49:261-276.

Duncan, G. B. 1955. Duncan multiple range test, Biometric 11:1-42

Fall, S. 1990. Improvement of nitrogen level in ruminant's diet based on Cereal straw: The problem of dissemination of research results on utilization of urea and browse plants as nitrogen sources. Addis Ababa, Ethiopia.

Feyera, T. and Animut, G. 2011. Effect of supplementing sole wheat bran, Acacia Albida leafmeal and their mixture on feed intake and carcass characteristics of Horro sheep fed vetch (Lathyrus sativus) haulm b a s a $1 \quad d$ i e t. www.pjbs.org/pjnonline/fin 1893p df

Ikhatua, U. J. and Olayiwole, M. B. 1982. 
Dressing percentage and carcass characteristics of Bunaji bulls fattened on varying inclusion levels of groundnut haulms and maize offal

Seasonal effect on Performance of feedlot bulls. Journal Animal Production Research. 2(2): 99111.

Ikhatua, U. J. and Adu, I. F. 1984. A comparative utilization of groundnut haulms and Digitaria smutsii hay by Red Sokoto goats. Journal of Animal Production Research 4:145-152.

Irshad, A., Kandeepan, G., Kumar, S., Ashish, K. A., Vishnuraj, M. R. and Shukla, V. C. 2012. Factors influencing carcass composition of livestock: A review: Journal of Animal Production Advances, 2012.3(5): 177-186

Iyeghe-Erakpotobor, G., T, Aliyu, R. and Uguru J. 2006. Evaluation of concentrate, grassand legume combinations on performance and nutrient digestibility of grower rabbits under tropical condition. African Journal of Biotechnology 4 (20) Pp2004-2008. http://www.academicjournals .org/AJB.

Jabbar, M. A. and Anjum, M. I. 2008. Effect of diets with different forage to concentrate ratio for fattening of Lohi lambs. Pakistan Veterinary 28 (3) 150-152.

Jaddalla, J. B., Mekki, D. M. and Mohammed, T.A. 2012. Effect of supplementation of dry season grazing with Groundnut haulms on nutrients utilization and sheep performance in West Kordofan state, Sudan. Journal of Animal Production Advances 2(10):462468.

Lakpini, C. A. M. and Adu, I. F. 1987. A note on concentrates: Legume hay ratio in fattening Yankasa Sheep . Journal of Animal production 14 (1 and 2): 135-137.

Lamidi, O. S., Omokanye, A. T. and Dung, D. D. 2006. Short-term Intake and insacco Degradation of Mixtures of Groundnut haulms and Gliricidia sepium by Ruminants in the Northern Guinea Savanna Zone of Nigeria. Journal of Animal and Veterinary Advances 5 (12):11291132.

Lamidi O. S., Adamu, A. M. Ehoche, O. W. and Alawa, J. P. 2007. Replacement value of sundried Broiler litter for cotton seed cake in the fattening diet for Bunaji bulls. Journal of Animal production Research 20(1-2):99-112.

Lamidi, O. S., Adeyinka, I. A., Alawa, C. B. I., Alibalogun, R. and Barje, P. P. 2008. Survey of Dry season feed Resources for smallholder fattening schemes in Northern Nigeria. Asian Journal of Animal and Veterinary Advances 3(2):9297.

Lamond, D. R. 1970. The influence of under-nutrition on reproduction in the cow. Animal Breeding Abstracts., 38:358-372

Loch, D. S. 1977. Brachiaria decumbens (Signal grass)-A review with particulae reference to Australia. Tropical Grass-land 11 (2): 141157.

Madziga, I. I., Voh, A. A., Barje, P. P. and Goska D. Y. 2016. Dressing percentage and Carcass characteristics of four indigenous cattle breeds in Nigeria. Nigerian Journal of Animal Production, 43 (1):274-280.

Michael, T. W., Osujji, P. O. and Yimegnuhal, A. 2002. Effect of wheat bran supplementation at graded levels on changes in physical body composition in teff 
straw (Eragrostis tef) fed zebu (bos indicus) oxen of the Ethiopian highlands. Pp 99-109. Proceedings of $9^{\text {th }}$ annual conference of the Ethiopian Society of Animal Production(ESAP), Addis Ababa,Ethiopia, August30-31 2001.

Minson, D. J. 1971. The nutrive value of tropical pastures. Journal of the Australian Institute of Agricultural Science 37: 255-263.

Njie, M. and Reed, J. S. 1995. Potential of crop residues and agricultural byproducts for feeding sheep in a Gambian village. Animal Feed Science and Technology, 52:313323.

NRC, 2000. (National Research Council). Nutrient Requirement of Beef Cattle. $7^{\text {th }}$ Revised Edition National Academic Press Washington, DC, U S A http:/www.nap.edu/books/030906 9343/html.

Olayiwole, M. B., Ahmed, M. B. and Bello, T. D. 1975. Feedlot $\mathrm{p}$ e $\mathrm{r}$ f o r m a n c e a n d carcasscharacteristics of steers fed high protein and high energy ration. Nigerian Journal of Animal Production 2 (2):270-276

Olayiwole, M. B., Buanendran, V., Fulani, I. J. and Ikatua, J. U. 1981. Intensive fattening of indigenous breeds of cattle in Nigeria. World Review of Animal Production, vol. xvii, No. 2.pp 7177.

Olorunnisomo, O. A., Adewumi, M. K. and Babayemi, O. J. 2006. Effects of nitrogen level on the utilization of maize offal and sorghum brewers' grain in sheep. Livestock Research for Rural Development
18(1) 2006.

Olorunju, P. E., Ntare, B. R., Babalola, O. A. and Alabi, O. 1996. Proceeding of a workshop on Nationally coordinated groundnut research project 25-29 September 1995. Zaria Nigeria, 47 pp.

Ranjhan, S. K. 1993. Animal Production in the Tropics, $3^{\text {rd }}$ Edition, New Delhi India.

Roth, M. T. P., Resende, F. D., Reis, A., Siqueira, G. R., Fraria, M. H. and Berchielli, T. T. 2009. Performance and carcass characteristics of beef cattle fed with Ammoniated Marandu grass hay. Revista Brasileira de zootecnia vol 38 no 9 Vicosa 2006

Rotta, P. P., Padro, R. M., Padro, I. N., Valero, M. V., Visentainer, J. V., Silva, R. R. 2009. The effect of genetic groups, nutrition, finishing systems and gender of Brazilian Cattle on carcass characteristics and beef composition and appearance. A review: Asian Australasian Journal of Animal Science, 2009(22)1718-1734.

Sampaio, C. B., Detmann, E. Paulino, M. F. Valadares, Filho, S. C. De Souza, M. A., Lazzarini, I., Rodrigues Paulino, P. V. and Queiroz, A. C. 2010. Intake and digestibility in cattle fed lowquality tropical forage and supplemented with nitrogenous compounds. (Abstract) Tropical Animal Health and Production 42(7):147-9.

Sauvant, D., Heuze, V., Tran, G. and Lebas, F. 2015. Maize and hominy feed. Feedipedia.org/node/712 $15: 29$

SAS 2002. INSTITUTE inc. SAS/STAT user's guide. 6.03 Edition, Gray $\mathrm{NC}, \mathrm{USA}$ 
Dressing percentage and carcass characteristics of Bunaji bulls fattened on varying inclusion levels of groundnut haulms and maize offal

Tarawli, A- R. and Quee, D. D. 2014. Performance of groundnut (Arachis hypoaea $L$ ) varieties in two agro-ecologies in Sierra Leone.African Journal of Agricultural Research 9(19):1442-1448.

Vantsawa, P. A., Ogundipe, S. O. Dafwang, I. I. and Omage, J. J. 2007. Replacement value of Dusa (Locally Processed Maize Offal) for Maize in the Diet of Egg Type chicks (0-8 weeks). Pakistan Journal of Nutrition. http://scialert.net.abstract/Adoi $=p$ jn.2007.530.533

Warly, L., Matsui, J., Harumoto, T. and
Fujihara, T. 1992. Study on the utilization of Rice straw by sheep 1. The effect of soybean meal supplementation on the voluntary intake of rice straw and ruminal fermentation. Asian-Australian Journal of Animal Science 5:687693.

Received: $25^{\text {th }}$ August, 2016 Accepted: $12^{\text {th }}$ March, 2017 